\title{
Reflections on the Arab Uprisings
}

\author{
Samir Makdisi
}

\begin{abstract}
This chapter offers reflections on the Arab uprisings grouped under four headings: (1) the entrenchment of autocracy in the region, (2) the unravelling of autocracy, (3) the uncertainty of the transition process, and (4) the challenges of sustaining democratic transitions.

Among the primary factors underlying the general entrenchment of Arab autocracy, at least prior to the uprisings, are the relative abundance of oil resources and the region's multi-faceted conflicts, along with all their attendant disruptive foreign interventions.

Youth unemployment rising to very high levels and the persistence of deep economic inequality were important factors contributing to the uprisings. They were also reinforced by long frustrated aspirations for greater freedom and political participation on the part of social groups that have felt largely excluded from the benefits of economic development.

As of late 2016 the outcome of the uprisings remains highly uncertain especially with the rise to power of strictly fundamentalist groups and the ensuing armed conflicts that have come in their wake. The struggle between forces pushing for a move towards democracy and those pushing for the maintenance and/or regeneration of autocracy is presently in full play.

Transition experiences point to two fundamental challenges facing the consolidation of democratic transitions: firstly that the political victors be able to move in the direction of establishing genuinely representative and accountable political institutions. Secondly that they succeed in implementing an inclusive socio-economic strategy that not only focuses on growth and expanding employment opportunities but also eliminates 'elite capture' of the public sector.
\end{abstract}

\section{Introduction}

The Tunisian uprising of December 2010 ushered in what seemed to be a new political phase in the Arab world, namely the beginnings of the unravelling of Arab autocracy. It was followed by the Egyptian uprising in January 2011 and later the same year by uprisings in Syria, Libya and Yemen. However, five years

(C) SAMIR MAKDISI, 2017 | DOI 10.1163/9789004336452_003

This is an open access chapter distributed under the terms of the CC-BY-NC License.mir Makdisi - 9789004336452 
on this trajectory is yet to take hold region-wide and prospects for democratic transitions in the foreseeable future remain highly uncertain. Tunisia may be forging ahead successfully along a democratic path, but Egypt's democratic course appears hesitant while in the other three countries the uprisings have turned into civil wars intertwined with outside military intervention, the case of Syria being especially tragic.

In the longer run, the uprisings may yet prove to be the catalyst that opened the door to a region-wide process of democratisation. However, as of late 2016 - with a few exceptions, Lebanon and Tunisia among them-autocracy continues to reign, though of course in varying forms and to different degrees from one country to another.

With the objective of shedding some light on the political economy of potential democratic transitions in the Arab region this paper offers reflections on the uprisings grouped under four headings: (1) background - the entrenchment of autocracy in the region, (2) the unravelling of autocracy in a few of the Arab countries, (3) the uncertainty of the transition process towards democracy, and (4) the economic and political challenges of sustaining democratic transitions, once initiated. These reflections draw on published work of the author, referred to in the text.

While these reflections focus on the Arab region as a whole, we should remain cognisant of the fact that the underlying factors of the uprisings vary from one case to another, as does the role of domestic elements in undermining the autocratic order. These elements seem to have been more dominant and decisive in the cases of Tunisia and Egypt than in the other three cases. This in turn might have contributed to the apparent democratic success of Tunisia in the wake of its uprising, and the averting of armed domestic conflict in Egypt though the democratic process is yet to take hold.

\section{On the Entrenchment of Arab Autocracy}

A number of democracy indices are employed in the empirical literature. In this chapter we refer to two of them: the commonly used Polity IV index, which includes data going back many years, and the more recent and comprehensive The Economist Intelligence Unit (EIU) Democracy Index, which begins with 2006 (Tables 2.1 and 2.2 below). They reveal the general entrenchment of autocracy in the Arab region from the end of the Second World War, when most of the Arab countries became independent, up to the present time.

The Polity data include information only on the institutions of the central government and on political groups acting, or reacting, within the scope of 
TABLE 2.1 Polity IV scores across Arab countries.

\begin{tabular}{llllllllll}
\hline & $\mathbf{1 9 7 0}$ & $\mathbf{1 9 8 0}$ & $\mathbf{1 9 9 0}$ & $\mathbf{2 0 0 0}$ & $\mathbf{2 0 1 0}$ & $\mathbf{2 0 1 1}$ & $\mathbf{2 0 1 2}$ & $\mathbf{2 0 1 3}$ & $\mathbf{2 0 1 4}$ \\
\hline Libya & -7 & -7 & -7 & -7 & -7 & -77 & -77 & -77 & -77 \\
Bahrain & - & -10 & -10 & -9 & -5 & -8 & -10 & -10 & -10 \\
Qatar & - & -10 & -10 & -10 & -10 & -10 & -10 & -10 & -10 \\
Saudi & -10 & -10 & -10 & -10 & -10 & -10 & -10 & -10 & -10 \\
Arabia & & & & & & & & & \\
Syria & -9 & -9 & -9 & -7 & -7 & -7 & -9 & -9 & -9 \\
Kuwait & -9 & -10 & -66 & -7 & -7 & -7 & -7 & -7 & -7 \\
Egypt & -7 & -6 & -6 & -6 & -3 & -2 & -88 & -4 & -4 \\
Morocco & -9 & -8 & -8 & -6 & -6 & -4 & -4 & -4 & -4 \\
Jordan & -9 & -10 & -4 & -2 & -3 & -3 & -3 & -3 & -3 \\
Algeria & -9 & -9 & -2 & -3 & 2 & 2 & 2 & 2 & 2 \\
Iraq & -7 & -9 & -9 & -9 & 3 & 3 & 3 & 3 & 3 \\
Lebanon & 5 & -77 & -66 & -66 & 6 & 6 & 6 & 6 & 6 \\
Tunisia & -8 & -9 & -5 & -3 & -4 & -88 & -88 & -88 & 7 \\
\hline
\end{tabular}

SOURCE: POLITY IV DATA SERIES, VERSION 2014.

Note: The Polity IV scheme consists of six component measures that record the key qualities of executive recruitment, constraints on executive authority, and political competition. It also records changes in the institutionalised qualities of governing authority. The 'Polity Score' captures this regime authority spectrum on a 21-point scale ranging from -10 (hereditary monarchy) to +10 (consolidated democracy). They can also be converted to regime categories, for which a three-part categorisation is recommended: 'autocracies' ( -10 to -6$)$, 'anocracies' ( -5 to $+5)$ and 'democracies' (+6 to +10$)$; there are also three special values $--66,-77$ and -88 - representing, respectively, periods of interruption (foreign occupation), interregnum (breakdown of central authority) and transition during which new institutions are being set up.

that authority. It does not include a consideration of groups and territories that are actively removed from that authority (i.e. separatists or 'fragments'; these are considered to be separate, though not independent, polities) or segments of the population that are not yet effectively politicised in relation to central state politics.

Numerous past and more recent analyses have addressed the question of lagging democracy in the Arab region compared to other regions (Table 2.3), or what has been termed Arab exceptionalism (see Salameh, 1994). These vary from a broad historical viewpoint to more focused analyses of specific underlying factors. Various historical, religious, social, ethnic, political, economic, and colonial explanations of this phenomenon have been posited. Space limitations 
TABLE 2.2 Ranking of Arab countries according to the EIU democracy index, 2010-2014.

\begin{tabular}{|c|c|c|c|c|}
\hline & 2010 Rank & 2010 Score & 2014 Rank & 2014 Score \\
\hline Tunisia & 145 & 2.79 & 79 & 6.31 \\
\hline Lebanon & 86 & 5.82 & 98 & $5 \cdot 12$ \\
\hline Iraq & 112 & 4.00 & 111 & 4.23 \\
\hline Mauritania & 115 & 3.86 & 112 & 4.17 \\
\hline Morocco & 116 & $3 \cdot 79$ & 116 & 4.00 \\
\hline Algeria & 125 & $3 \cdot 44$ & 117 & 3.83 \\
\hline Libya & $15^{8}$ & 1.94 & 119 & 3.80 \\
\hline Kuwait & 114 & 3.88 & 120 & $3 \cdot 78$ \\
\hline Jordan & 117 & $3 \cdot 74$ & 121 & $3 \cdot 76$ \\
\hline Qatar & 137 & 3.09 & 136 & 3.18 \\
\hline Egypt & 138 & 3.07 & 138 & 3.16 \\
\hline Oman & 143 & 2.86 & 139 & 3.15 \\
\hline Djibouti & 154 & 2.20 & 145 & 2.99 \\
\hline Bahrain & 122 & $3 \cdot 49$ & 147 & 2.87 \\
\hline Yemen & 147 & 2.64 & 149 & 2.79 \\
\hline UAE & 148 & $2.5^{2}$ & $15^{2}$ & 2.64 \\
\hline Sudan & 151 & 2.42 & 153 & 2.54 \\
\hline Saudi Arabia & 161 & 1.84 & 162 & 1.82 \\
\hline Syria & 153 & 2.31 & 163 & 1.74 \\
\hline
\end{tabular}

SOURCE: EIU REPORTS, 2011 AND 2014.

Note: The EIU index is a weighted average of 60 indicators grouped into five different categories: electoral process and pluralism, civil liberties, functioning of government, political participation, and political culture. In addition to a numeric score and a ranking, the index categorises countries as one of four regime types - full democracies (a score of 8-10), flawed democracies (6-7.9), hybrid regimes (4-5.9), and authoritarian regimes (0-3.9).

do not permit me to go into a review of this literature here. ${ }^{1}$ I would simply like to refer to two factors that seem to be of primary importance in explaining the persistence of what has been termed the Arab democracy deficit, at least until

1 The following references are but a very small sample of writings starting with the early $1980 \mathrm{os}$ and representing differing viewpoints on this question: Center for Arab Unity Studies, 1983; Sharabi, 1988; Hudson, 1991; Kedourie, 1994; Salameh, 1994; Waterbury, 1994; Al Naqeeb, 1996; Harik, 2006; Bichara, 2006; Noland, 2008; Diamond, 2010; Amin et al., 2012; Chaney, 2012; Haseeb, 2013; Elbadawi and Makdisi., 2011; Aldashev et al., 2013. 
TABLE 2.3 EIU index across regions, 2010-2014.

\begin{tabular}{lllll}
\hline & $\begin{array}{l}\text { EUI index } \\
\mathbf{2 0 1 0}\end{array}$ & $\begin{array}{l}\text { EIU index } \\
\mathbf{2 0 1 1}\end{array}$ & $\begin{array}{l}\text { EIU index } \\
\mathbf{2 0 1 3}\end{array}$ & $\begin{array}{l}\text { EIU index } \\
\mathbf{2 0 1 4}\end{array}$ \\
\hline North America & 8.63 & 8.59 & 8.59 & 8.59 \\
Western Europe & 8.45 & 8.40 & 8.41 & 8.41 \\
Eastern Europe & 5.55 & 5.50 & 5.53 & 5.58 \\
Latin America and & 6.37 & 6.35 & 6.38 & 6.36 \\
Caribbean & & & & \\
Asia and Australasia & 5.53 & 5.51 & 5.61 & 5.70 \\
MENA & 3.43 & 3.62 & 3.68 & 3.65 \\
Sub-Saharan Africa & 4.23 & 4.32 & 4.36 & 4.34 \\
Total & 5.46 & 5.49 & 5.53 & 5.55 \\
\hline
\end{tabular}

SOURCE: EIU REPORTS, 2011 AND 2014.

the outbreak of the recent uprisings - the relative abundance of oil resources and the region's multi-faceted conflicts, including the unresolved Arab-Israeli conflict, along with all their attendant disruptive foreign interventions (see Elbadawi and Makdisi, 2017). ${ }^{2}$

The 'oil curse' effect - the trade-off, between economic welfare and political rights, associated with the relative abundance of oil resources-is well established in the literature (for a review, see Ross, 2014) though not necessarily a matter of universal agreement (Haber and Menaldo, 2011). ${ }^{3}$ Nonetheless, at the political level its negative political impact on governance specifically in the oil rich countries is perhaps generally recognised. But at the economic level the influence of abundant oil wealth is more varied. While various beneficial

2 It is worth noting here that the persistence of autocracy in most Arab countries despite their notable socio-economic development since attaining independence after World War II does not seem to conform to the influential modernisation hypothesis that posits a positive correlation between development and democracy (Lipset, 1959 and 1960). By contrast, it appears to be generally more pronounced for the other developing regions of the world.

The modernisation hypothesis has its supporters as well as its critics who have advanced alternative theories of transition. Among its defenders, see, for example, Barro, 2015; Faria et al., 2014; among its critics, see Przeworski et al., 2000; Przeworski, 2004 and 2009; and Acemoglu et al., 2008 and 2009.

3 The authors argue that this oil and mineral reliance does not promote dictatorship over the long run even after taking into account a host of conditional effects suggested by the literature. This, however does not necessarily imply that there are no specific instances in which resource rents might have helped to sustain a dictatorship. 
effects on development can rightly be pointed out (Luciani, 2012), recent empirical work has drawn attention to the required role of fiscal and monetary policies in countering its negative impact (e.g. the hindrance of economic diversification) thereby ensuring that oil resources are efficiently used for developmental purposes. This outcome, it is argued, would in large measure hinge on the efficacy and accountability of the institutions in place, notably fiscal institutions, keeping in mind that Arab fiscal institutions remain wanting in this regard (El Anshasy et al., 2015).

Equally important, perhaps more so, is the persistence of a conflictual regional environment. According to available data for the period 1990-2013 over 6o per cent of all Arab countries experienced at least one conflict, which makes the Arab region one of the most conflict-prone regions, accounting for around 17 per cent of world conflicts. ${ }^{4}$ Of course at the centre of the region's conflictual environment is the unsettled but simmering Arab-Israeli conflict, which goes back to 1948 and does not have a parallel in other regions, at least in recent history.

Indeed, conflicts are found to have a uniquely negative effect on the democratisation process in the Arab region (keeping in mind that this effect can vary significantly from one country to another) partly because these conflicts have been exploited by incumbent autocratic regimes to justify their rule and to escape the consequences of their national failures (for a detailed analysis of the conflict effect, see Elbadawi and Makdisi, 2017). The Palestinian question remains unresolved while the settlement of civil wars in the pre-2010 period did not lead to a significant change in the political regimes of the war-torn countries involved. The outcome of the post-uprising civil conflicts is yet to be determined.

By contrast, in other regions of the contemporary world civil conflicts have mostly been followed by a move towards democracy, noted reversals notwithstanding (Jai Kwan, 2008), a contrast that appears to support the argument for the Arab region's exceptionalism.

\section{On the Unravelling of Autocracy in a Few Arab Countries}

Whatever the immediate triggers for the Tunisian and Egyptian uprisings, a gamut of interacting economic, political and other underlying factors have been building up over the years for a push towards a democratic space in the

4 See Uppsala Conflict Data Program (UCDP) (2016). The UCDP defines conflict as 'a contested incompatibility that concerns government and/or territory where the use of armed force between two parties, of which at least one is the government of a state, results in at least 25 battle-related deaths'. 
region, initiated, as it turned out, by the successful overthrow of the Tunisian autocracy. However-as noted in the following section-given existing regional realities, how successful additional democratic breakthroughs in the region are, at least in the shorter run, remains to be seen.

In the economic domain two important factors underlying the uprisings are unemployment, increasing over the years to very high levels especially of youth unemployment, and the persistence of deep economic inequality (Hakimian, 2013; Bibi and Nabli, 2010), especially—as noted below_after the process of privatisation of the national economies started to take a strong hold. Accompanying these factors are the long frustrated aspirations for greater freedom and political participation on the part of social groups that have felt largely excluded from the benefits of economic development. Such aspirations have been reinforced by greater openness, both within the Arab region and towards the outside world - a result of the technological advances in information, and in consequence by a growing awareness of the attractions of democracy.

In the period following the break-up of the Soviet Union, the gradual shift in the development paradigm, from a nationalist developmental strategy based on a public sector oriented economy to a market economy, had major consequences. For all the economic benefits of this shift the private sector failed to generate the sufficient number of employment opportunities that state and public sector institutions had previously provided (no matter how inefficiently), especially for young people. Analysts attribute this failure primarily to misguided policies — often uneven, hesitant and incomplete—and to weak institutional performance characterised by cronyism and corruption (Ansani and Daniele, 2012). ${ }^{5}$

Whatever the causes of faltering Arab growth, in the period 2005-2010 Arab youth unemployment reached high levels averaging more than 25 per cent and it continued to rise in both 2011 and 2012 (the highest rate among various developing regions. See International Labor Organization (ILO), 2013). This growing unemployment rate tended to weaken regimes' hold on power and their authoritarian bargain - that is to say, their ability to trade off public goods and other economic benefits for political rights and participation-more so in non-oil-producing than in oil-rich counties. As some writers have put it, the Arab social contract started to unravel (Amin et al., 2012).

Furthermore, the declining economic role of the state has helped promote the growth and empowerment of independent civil society organisations that traditionally press for economic and political reforms. The Arab ruling classes

5 Institutional performance, it has been argued, plays a determining role in explaining differences in outcomes with regard to per capita income (Acemoglu and Robinson, 2008). 
have attempted to counter this trend by co-opting both business and intellectual elites and by forging partnerships between highly placed government officials and business tycoons, who basically engage in rent seeking activities. In practice, this has meant that a few groups have been favoured, receiving the larger part of the benefits of growth to the relative exclusion of the majority of the populace; this phenomenon, in turn, has bred growing resentment. While the trend in income inequality may not have changed significantly in recent decades (Hakimian, 2013), ${ }^{6}$ disillusionment with economic prospects has led to what has been termed 'unhappy growth' (Amin et al., 2012).

The impact of greater openness, both within the Arab region and with the outside world, on the weakening of the authoritarian bargain is perhaps selfevident. It helps civil society organisations, including those run by students, women and other social groups, to press harder for political reform. And, as amply demonstrated by the recent uprisings, deep-seated ambitions-not only with regards to socio-economic advancement but also to greater freedom and political participation-exist in large segments of the populace that have felt disenfranchised and largely excluded from the benefits of economic development.

The unexpected success of mass, street mobilisation in both Tunisia and Egypt acted as a spark for similar mass movements in other Arab countries: the younger generations in particular pressed successfully for the dismantling of the autocratic regimes of both countries, via mostly peaceful means including intensive use of rapidly spreading social networks.

These uprisings of Arab youth were influenced by two underlying factors. Primarily they had lost faith in the role of traditionalist, reformist political parties, which had proved incapable — for whatever reason — of acting as agents of political change and therefore had to be left behind. But also, they were influenced by the ripple effects of the important democratic changes that have taken place in other regions of the developing world.

Nonetheless, the region's democratic prospects remain highly uncertain, a matter to which we now turn.

6 The authors of the work cited point out that data tend to place the MENA region's income distribution levels between those of Africa and Asia. Overall, the region has moderately high levels of inequality: some countries, such as Egypt, are on the lower end of the scale of inequality, with an income distribution closer to the Asian pattern; others, such as Iran, have fairly high inequality, closer to African levels. A key finding is that despite huge structural changes in these economies, income distribution has not changed by much. Over the last few years, there have been indications of a worsening tendency, but the trend is not noticeable when compared to worsening income distribution in fast-growing Asian countries. 
As already noted, of the five Arab countries where uprisings have taken place ${ }^{7}$ only one, Tunisia, appears to be moving towards a genuine democracy as attested by the approval of a modern constitution in January 2014, and the free parliamentary elections of October 26 and presidential elections on December 21 of the same year, and by the generally relatively peaceful transfer of power among its major political contestants.

In Egypt the army ousted the elected president-Mohamed Morsi, a member of the Muslim Brotherhood — on July 3, 2013 after massive demonstrations and street confrontations between opponents and supporters of the Brotherhood. The result of the presidential elections that followed in June 2014, won by the head of the army, Abdelfattah al-Sisi, is described by some writers as a return to a modified Mubarak type regime. Despite the adoption of a new constitution in early 2014 and the parliamentary elections that took place in October 2015 (characterised by a relatively low turnout) and were completed in December of the same year, authoritarian or exclusionary forms of governance continue to exist; the process of overcoming them and moving towards a genuine democracy is yet to take place (See El Mikawy et al., 2017).

The uprisings in the other three countries have turned into civil wars and regional conflicts with confessional and/or ethnic overtones that, as of late 2016, have yet to be settled. In particular, the Syrian civil war has attracted armed fundamentalist groups (especially DAISH (Islamic State in Iraq and the Levant_ ISIL) and Al Nusra) that oppose the regime, but also armed parties from neighbouring countries that support it, notably Lebanon's Hizbollah. The fundamentalists have come to control large segments not only of Syria but also Iraq, in turn widening the scope of the conflict and triggering foreign military interventions: firstly, us aerial bombing in support of Kurdish units fighting ISIL in northern Syria, and a year later (end September 2015) wideranging Russian aerial bombing in support of the regime. The Yemen civil war that erupted in early 2015 witnessed, in March of that year, the beginning of an aerial bombing campaign by a Saudi-led coalition in support of Yemeni parties fighting the 'Houthis' and their allies, a grouping that has its own regional supporters and that had earlier managed to seize power and establish control over the capital and a large part of the country. Libya, after the fall of the Gaddafi regime (a collapse that Western aerial bombing helped bring about), failed to

7 Bahrain has witnessed many popular demonstrations demanding political reform, but so far, with the assistance primarily of Saudi Arabia, the regime has succeeded in suppressing reform demands while thwarting any potential popular uprising. 
make a stable transition and in 2014 a renewed civil war broke out between rival organisations seeking control of the country or parts of it.

Thus, while the uprisings have shaken the foundations of autocracy in parts of the Arab world and initially gave rise to a glimmer of hope for regional democratic change, the civil conflicts that have subsequently emerged have further strengthened the region's conflictual environment. In consequence, fed by emerging sectarian divisiveness, and in particular the rise to power of strict fundamentalist groups, the negative impact of conflicts in the region on the process of democratisation has further intensified, posing the threat of democratic reversals in those countries that managed to break out of the grip of entrenched autocracies.

What might explain the rise to power of strict fundamentalist groups thatin brutal fashion-employ religion as an instrument to achieve their political goals, lies outside the purview of this paper. ${ }^{8}$ Unless ISIL and similar sectarian movements are contained and reversed, their ascendancy will represent an unprecedented threat to any potential transitions towards democracy. In fact, were fundamentalist parties to dominate the political scene in any postuprising phase, it would be difficult to envision such transitions, both in individual countries and region-wide. ${ }^{9}$

Tunisia apart, the failure, so far, of democratic transitions to take hold in the wake of the uprisings will hopefully constitute only a passing, albeit a tragic, phase that will yet pave the way for a stable democratic change in the Arab world-however gradual, hesitant or difficult that change might prove. The experience of other regions in this regard, as outlined below, is instructive.

What should be kept in mind is that once the process towards democratisation begins to unfold on a solid basis in the region, it will tend to gain added momentum, positively affecting neighbouring countries that are yet to democratise. The reason for this is that societies located in democratic

8 In this regard, a number of questions would need to be addressed: Do these groups represent a response on the part of poorer segments of the population to political and economic exclusion? Are they simply the product of a strict fundamentalist ideology, and/or certain fundamentalist regimes and/or foreign powers that initially wished to use them for their own ends? Do they constitute a response to past Western colonialism and continued interventions in the affairs of the region? Or can, perhaps, a combination of all these and other factors explain their rise to power; a rise that has occurred to such an extent that the us and other Western countries, whatever their possible initial roles in fostering these groups, have come to consider them a threat to their own national interests.

9 Some writers caution that whereas Islam is compatible with democracy, Islamist fundamentalism is not: Islamist movements may embrace election ballots but merely as a political exigency while continuing to reject the concept of political pluralism that underlies democratic governance (see Tibi, 2008). 
neighbourhoods become more likely to move towards democratic transitions: the significance of resource rents as a constraint to democratic transition in democratic regions greatly diminishes, even for highly resource-endowed societies (Elbadawi and Makdisi, 2017). Hence it can be argued that were the current Arab uprisings to eventually swell into a major regional phenomenon, that phenomenon might even spread to those societies that are highly resourceendowed and so far have remained unaffected. ${ }^{10}$

Moreover, as has been pointed out, for any given region the greater the number of countries that succeed in moving towards a consolidated democracy the less important is the potential threat of reversal (e.g. see Poast and Urpelainen, 2015).

The region is thus at a point in its post-uprisings phase where the struggle between the forces pushing for a move towards democracy and those pushing for the maintenance or regeneration of autocracy is in full play. ${ }^{11}$ Of primary concern is that once a substantive move towards democratic governance is established, as in the case of Tunisia, various political and economic challenges would need to be successfully addressed in order to ensure a viable transition - a matter we will now take up.

5

\section{On the Political and Economic Challenges of Sustaining Democratic Transitions}

The experiences of other regions teach us that in the wake of democratic breakthroughs the consolidation of a democracy is not necessarily a foregone conclusion. Numerous reversals have taken place, though at a decreasing rate over the decades since 1960 and with notable variations from one region to another

10 A number of writers have written on the potential region-wide spread of democracy in the wake of the uprisings. For example, Haseeb (2013) points out that the emergence of an Arab democracy wave hinges on a set of four factors that, 'when co-incident are decisive, and these are: breaking the "barrier of fear"; non-violent resistance; sufficient national cohesion and popular sentiment; and the (positive) stance of the armed forces vis-à-vis the uprisings'.

11 It has been argued that the Arab Spring was made possible when the accumulated economic and political failures of the Arab political order led to a convergence of visions on the part of the Islamist and secular elements in society, notably in Tunisia and Egypt. Their failure to maintain consensus on a common platform of a viable social contract has contributed to the emergence of an authoritarian counter revolution. (El Affendi, 2017). 
(Kapstein and Converse, 2008). ${ }^{12}$ Equally, the transition towards democratic governance may not be accomplished quickly but may go through phases of various forms of partial democracy as a prelude, over time, to more advanced forms of democracy. ${ }^{13}$

The experience of countries that have successfully consolidated their democratic transitions indicates major politico-institutional and socio-economic challenges that need to be met for this objective to be achieved.

At the politico-institutional level, a major challenge is the willingness and ability of the political victors in countries that mange to break the hold of autocratic rule to establish, or move in the direction of establishing, genuinely representative, accountable and transparent political institutions. Ideally these would guarantee basic human rights, primarily freedom of expression and free choice, and provide an opportunity for citizens to participate in the political process, institutionalising their right to make choices and challenge public policies, and to hold governments accountable. And therefore the issue of what type of institutions are in place and who is framing and enforcing policy decisions become paramount. ${ }^{14}$

12 According to the authors of the work cited, of the 123 democratisations that took place during the period 1960-2004, 67 gave rise to democratic regimes that survived 2004, while the remaining 56 episodes had ended in a return to authoritarianism by the end of that year. Among those democratisations that were reversed, several later underwent second, third, or even fourth episodes of democratisation. Although fewer than half $(47 \%)$ of the first-time democratisations were sustained, the survival rate of second-time democratisations approaches two-thirds (63\%). Four of the six cases of fourth-time democratisation survived through to the end of 2004. These trends are closely aligned with the improving success rate of all democratisations over time. They point out that political institutions play the crucial role in democratic consolidation, especially institutions that place effective constraints on executive power.

13 The classifications adopted in both Polity IV and the EIU Democracy Index refer to political regimes that lie in-between autocracies and democracies. In a recent study by $\mathrm{Mu}-$ kand and Rodrik (2015) on the political economy of the liberal democracy, the authors point out it is characterised by three kinds of rights: property (elite interest), political (majority interest) and civil (minority interest). They explain why in the West liberal democracies came to be established while in the developing world most democracies that have emerged are electoral democracies that provide property and political but not civil rights.

14 Recent research, focusing on oil-rich countries, has drawn attention to the critical role of monetary and fiscal institutions in promoting the development desired, and specifically in countering the negative economic effects of abundant oil revenues. For analyses of this issue see the papers presented at a workshop organised by the Economic Research Forum in Kuwait, under the title 'Monetary and Fiscal Institutions in Resource-Rich 
The political path to enforcing democratic reform (e.g. constitutional revisions, organisation of elections, etc.) will differ from one country to another (see UNDP, 2011). What matters is that genuine democratic institutions become established and operable and secure, whereby the toppled elite is not merely replaced by a new elite with a similar pattern of behaviour. Under these circumstances we need not fear an initial electoral success of particular politico-religious groups. Their initial success can later be democratically contained, if not reversed, especially if they fail at governing.

Developments in Tunisia demonstrate this question in a very encouraging way. The successful election of the National Constituent Assembly in October 2011 was an important step in the country's transition process. The Islamist Ennahda party emerged as the most important single political party, capturing around 40 per cent of parliamentary seats. But it agreed to join a coalition government whose main task was to guide the process of moving towards a new constitution. Despite ensuing political crises, social unrest and an economic slowdown, a successful national dialogue among the competing political parties, including Ennahda, eventually led to the adoption of a modern constitution and the transfer of power to an independent technocratic government. The peaceful legislative and presidential elections that took place in OctoberDecember 2014 demonstrated that Tunisia had been undergoing a successful democratic transition, though major political and economic challenges lie ahead (see Boughzala and Ben Romdhane, 2017).

In contrast, in the case of Egypt the move to establish accountable political institutions and a space for democratic political competition in the wake of the uprising has so far been, at best, only partially successful. As a recent paper argues (El Mikawy et al., 2017), while the constitution passed in 2014 respects social and economic rights, it continues to sanction an authoritarian bargain whereby security precedes freedoms. The fact that certain institutions such as the military continue to enjoy an autonomy that shields them from real political accountability renders uncertain the future of liberal democracy in the country.

At the socio-economic level what would be required is the design and implementation of a broad based and what has come to be referred to as inclusive strategy, one that should create expectations that growth, expanding employment opportunities, and equity will play a major role in the transition to a new economy (see Makdisi, 2015). This strategy would imply modernising the public sector and, importantly, eliminating its 'elite capture' with a view to ensuring that emerging political and business interests in the transition phase

Arab Economies' (November 4-5, 2015), http://erf.org.eg/events/monetary-and-fiscalinstitutions-in-resource-rich-arab-economies/ (accessed on 7 April 2016). 
are not capable of obstructing the implementation of policies supportive of inclusive growth. ${ }^{15}$ At the same time, developmental experiences teach us that the extent to which developmental policies work depends on particular local, historical or institutional contexts.

Reconciling the objectives an all-inclusive strategy, basically implementing policies that at once promote growth and macro-economic stability while attending to the basic socio-economic needs of citizens, is of course not an easy task, especially when one considers the various social pressures and expectations that emerge during the transition process. Indeed, the record of democratic transitions elsewhere shows that such changes resulted, not infrequently, in economic recessions that either derailed or potentially could have derailed the process of substantive political reform. But, as noted above, if they are to succeed, it is a task that transition countries cannot avoid undertaking, with the determination that emerging political institutions assume the required supporting role. Of note are studies showing that transition countries that succeeded in implementing socio-economic reform have forged ahead economically more than those that failed to do so (Amin et al., 2012).

Chile offers a good example of a transition country that has been able to address the needs of the less privileged while implementing policies that have achieved growth and stability. Governmental policies supported low-income households, promoted education and allowed for investments in local health services and housing. Importantly, the government's social development programmes were accompanied by tax reform including putting in place a progressive income tax system. Increased social spending was, thus, matched by new sources of tax revenue (UNDP, 2011). A major lesson of the Chilean experience is that mobilising the resources necessary for financing the increased spending required if long neglected social needs are to be satisfied is of crucial importance for the maintenance of economic stability while addressing these needs. In this context it would be incumbent on the responsible authorities to avoid wasteful social spending that does not serve its intended purpose. Egypt's subsidy programmes are a case in point. Despite a high level of subsidy spending on safety net programmes, these programmes did not benefit the less privileged nor significantly address income and human poverty issues, though attempts have recently been made to improve their efficacy (El Mikawy et al., 2017).

Indeed, as recent research has shown with regards to Tunisia (e.g. Boughzala and Ben Romdhane, 2017), it would seem that the consolidation of the country's

15 As pointed out by some researchers, developmental opportunities are constrained not only by available resources and access to finance and trade but also by the established interests of the ruling elite rooted in existing political institutions (Currie-Alder et al., 2014). 
nascent democracy could very well depend on the success of the responsible authorities in coping with the country's existing socio-economic problems. Specifically, this implies the authorities' ability to formulate and implement a coherent economic strategy that responds to key economic and social demands, mainly those of the young people that led the revolt. In particular, policy priorities should include creating new employment opportunities and implementing inclusive development strategies that, among other objectives, aim at narrowing regional disparities while (as the Chilean experience demonstrates) generating the financial resources required to maintain economic stability. If such policies do not succeed, Tunisia could risk a period of retrogression, though given the country's human potential and its recent history, the probability of such a risk being realised seems low.

6

\section{Conclusion}

Given that the Arab uprisings are not yet a region-wide phenomenon, a fundamental political change towards democratic governance in any one individual country will necessarily face negative regional pressures emanating from the still existing, non-democratic regional neighbourhood. Similarly, negative external interventions could disrupt a potential democratic process in the region that may be viewed by the intervening powers as being contrary to their regional interests. As long as a highly conflictual regional environment continues to prevail, its corrosive impact will continue to manifest itself, one way or another, on political developments in the region.

These influences will not necessarily impede the process of moving towards democracy initiated by the dismantling of autocracy in any given individual country, as in the case of Tunisia, but they could help derail that process, as has been happening in the other countries where uprisings have taken place.

\section{References}

Acemoglu D. and J. Robinson (2008) 'The Role of Institutions in Growth and Development', Commission on Growth and Development. Working paper No.10 (Washington D.C.: World Bank), http://siteresources.worldbank.org/EXTPREMNET/ Resources/489960-1338997241035/Growth_Commission_Working_Paper_10_Role_ Institutions_Growth_Development.pdf (accessed on 7 April 2016).

Acemoglu, D., S. Johnson, J. Robinson, and P. Yared (2008) 'Income and Democracy', American Economic Review 98(3), DOI: 10.1257/aer.98.3.808808-42. 
Acemoglu D., S. Johnson, J. Robinson, and P. Yared (2009) 'Reevaluating the modernization hypothesis'. Journal of Monetary Economics, Vol. 56(8), DoI: 10.1016/ j.jmoneco.2009.10.002.

Aldashev, G, J.-P. Platteau and. P. Sekeris (2013) 'Seduction of Religious Clerics and Violence in Autocratic Regimes - with special emphasis on Islam' (Ms).

Al Naqeeb Khaldun (1996) The Struggle Between Tribe and Democracy (in Arabic), (London: Dar al-Saqi).

Amin, M., R. Assaad, N. al-Baharna, K. Dervis, R.M. Desai, N.S. Dhillon, A. Galal, Hafez Ghanem, C. Graham, and D. Kaufmann (2012) After the Spring: Economic Transitions in the Arab World (Oxford, Oxford University Press).

Ansani, A, and V. Daniele (2012) 'About a Revolution. The Economic Motivations of the Arab Spring', International Journal of Development and Conflict, 3(3), DOI: 10.1142/ S2010269012500135.

Barro R, (2015) 'Convergence and Modernization', Economic Journal, 125(585), DOI: $10.1111 /$ ecoj.12247.

Bibi, S. and M.K. Nabli (2010) "Equity and Inequality in the Arab Region". ERF Policy Research Report PRR33, Economic Research Forum, Cairo, Egypt. http://erf.org.eg/ wp-content/uploads/2016/o4/PRR33.pdf (accessed on 6 December 2016).

Bichara A. (2006) The Arab Question: Introduction to an Arab Democracy Manifesto, (Beirut: Center for Arab Unity Studies) (in Arabic).

Boughzala, M. and S. Ben Romdhane (2017) 'Transition from Autocracy to Democracy in Tunisia, Factors Underlying the Tunisian Uprising and the Prospects for Consolidating the Transition to Democracy', in Elbadawi, I and S. Makdisi (eds.), Democratic Transitions in the Arab World (Cambridge: Cambridge University Press).

Center for Arab Unity Studies (1983) The Crisis of Democracy in the Arab world, proceedings of a conference held in Limassol, Cyprus (in Arabic).

Chaney, E. (2012) 'Democratic Change in the Arab World, Past and Present', unpublished mimeo, Department of Economics, (Cambridge, Massachusetts: Harvard University).

Currie-Alder B., Kanbur R., Malone D.M., and Medhora R. (2014) International Development. Ideas, Experience, and Prospects (Oxford: Oxford University Press).

Diamond L. (2010) 'Why Are There No Arab Democracies?' Journal of Democracy, 21(1), http://www.journalofdemocracy.org/sites/default/files/Diamond-21-1.pdf (accessed on 7 April 2016).

El Affendi, A. (forthcoming) 'Overcoming Induced Insecurities: Stabilising Arab Democracies after the Spring' in Elbadawi, I. and S. Makdisi (eds.), Democratic Transitions in the Arab World (Cambridge: Cambridge University Press).

El Anshasy, A., K. Mohaddes and J.B. Nugent (2015) 'Fiscal Institutions and Macroeconomic Management in Resource-Rich Arab Countries', paper presented at a 
conference of the Economic Research Forum on 'Monetary and Fiscal Institutions in Resource-Rich Arab Economies', Kuwait, November 4-6.

Elbadawi, I. and S. Makdisi (2017) 'Explaining Democratic Transitions in the Arab World' in Elbadawi, I. and S. Makdisi (eds.) (2011) Democratic Transitions in the Arab World (Cambridge: Cambridge University Press).

Elbadawi, I. and S. Makdisi (eds.) (2011) Democracy in the Arab World, Explaining the Deficit (London and New York: Routledge).

Elbadawi, I., M. Goaied and M. Ben Taher (2015) 'Fiscal-Monetary Interdependence and Exchange Regimes in Oil-Dependent Arab Economies', paper presented at a workshop of the Economic Research Forum on 'Monetary and Fiscal Institutions in Resrouce-Rich Arab Economies', Kuwait, November 4-6.

El Mikawy, N., M. Mohieddin and S. El Ashmaouy (2017) 'Egypt: Pathways from Authoritarianism To Democracy: A Protracted Transition' in Elbadawi, I. and S. Makdisi (eds.), Democratic Transitions in the Arab World (Cambridge: Cambridge University Press).

Faria H.J., HM Montesinos-Yufa and DR Morales (2014) 'Should the Modernization Hypothesis Survive Acemoglu, Johnson, Robinson, and Yared? Some More Evidence', Econ Journal Watch, http://econjwatch.org/file_download/799/CompleteIssueJan2014.pdf\#page=18 (accessed on 5 April 2016).

Haber, S. and V. Menaldo (2011) 'Do Natural Resources Fuel Authoritarianism? A Reappraisal of the Resource Curse' American Political Science Review, 105(01), 1-26, DOI: $10.1017 /$ Sooo3055410000584.

Hakimian, H. (ed.) (2013) Inclusive Growth in MENA: Employment and Poverty Dimensions in a Comparative Context, Femise Research Programme Research No. FEM 35, 16 June (London: Middle East Institute and Economics Department, soAs) http:// eprints.soas.ac.uk/17319/3/Inclusive\%2oGrowth\%2oin\%2oMENA\%2o-\%2oEmployment\%2oand\%2oPoverty\%2oDimensions\%2oin\%20a\%2oComparative\%2o Context\%20\%28FEM3516_June\%202013\%29.pdf (accessed on 1 April 2016).

Harik I. (2006) 'Democracy, "Arab Exceptionalism", and Social Science', Middle East Journal, 6o(4), 664-84, DoI: 10.3751.60.4.12.

Haseeb, K. El-Din (2013) 'The Arab Spring Revisited', in K. El-Din Haseeb (ed). The Arab Spring: Critical Analyses (London and New York: Routledge) 4-16.

Hudson M. (1991) 'After the Gulf War: Prospects for Democratization in the Arab World', Middle East Journal, 45(3), http://www.jstor.org/stable/4328313.

International Labor Organization (ILO) (2013) Global Employment Trends 2013: Recovering from a second jobs dip (Geneva: ILO), http://www.ilo.org/global/research/ global-reports/global-employment-trends/2013/WCMS_202326/lang--en/index .htm (accessed on 5 April 2015).

Jai Kwan J. (2008) 'Mission Impossible? Democracy Building in Post-Civil War Societies' (Chicago: Midwest Political Science Association Annual Meeting), http:// 
government.arts.cornell.edu/assets/psac/spo8/MissionImpossible_PSAC.pdf (accessed on 5 April 2015).

Kapstein, E.B. and Converse, N. (2008) 'Poverty, Inequality, and Democracy. Why Democracies Fail', Journal of Democracy, 19(4), http://www.journalofdemocracy.org/ poverty-inequality-and-democracy-why-democracies-fail (accessed on 5 April 2015).

Kedourie, E. (1994) Democracy and Arab Political Culture (London: Frank Kass).

Lipset, S.M. (1959) 'Some Social Requisites of Democracy: Economic Development and Political Legitimacy'. American Political Science Review, 53(1).

Lipset, S.M. (1960) Political Man. The Social Bases of Politics (New York: Doubleday).

Luciani, G. (ed.) (2012) Resources Blessed, Diversification and the Gulf Development Model (Berlin: Gerlach Press).

Makdisi, S. (2015) 'The Unraveling of Arab Autocracy: Socioeconomic Factors in Context' in Ali Kadri (ed.) Development Challenges and Solutions After the Arab Spring (London: Palgrave Macmillan), Dor: 10.1057/9781137541406.

Mukand, S. and D. Rodrik, (2015) 'The Political Economy of Liberal Democracy' NBER Working Paper No. 21540, DOI: 10.3386/w21540.

Noland, M. (2008) 'Explaining Middle Eastern Political Authoritarianism I: The Level of Democracy', Review of Middle East Economics and Finance, 4(1), DoI: 10.2202/1475-3693.1057.

Poast, P. and J. Urpelainen (2015) 'How International Organizations Support Democratization. Preventing Authoritarian Reversals or Promoting Consolidation' World Politics, V. 67(1), 72-113, DoI: 10.1017/Soo43887114000343.

Przeworski, A. (2004) 'Economic Development and Transitions to Democracy' March, (MS), http://politics.as.nyu.edu/docs/IO/280o/transwp.pdf (accessed on 5 April 2015).

Przeworski, A. (2009) 'The Mechanics of Regime Instability in Latin America' Journal of Politics in Latin America, 2009(1), 5-36, https://www.ciaonet.org/attachments/14870/uploads (accessed on 5 April 2015).

Przeworski, A., J.A. Cheibub, M.E. Alvarez and F. Limongi (2000) Democracy and Development: Political Institutions and Material Well-being in the World, 1950-199o (Cambridge: Cambridge University Press).

Ross M. (2014) What Have We Learned about the Resource Curse? (Los Angeles), DoI: $10.2139 /$ ssrn.2342668.

Salameh, G. (ed.) (1994) Democracy without Democrats, the Renewal of Politics in the Muslim World (London: I.B. Tauris).

Sharabi, H. (1988) Neopatriarchy: A Theory of Distorted Change in Arab Society (New York: Oxford University Press).

Tibi, B. (2008) 'Islamist Parties: Why They Can't Be Democratic', Journal of Democracy, 19(3), DOI: 10.1353/jod.o.oooo. 
United Nations Development Programme (UNDP) (2011) Pathways to Democratic Transitions. Summary Report on Country Experiences, Lessons Learned and the Road Ahead, International Forum Report, Cairo June 5-6, http://www.eg.undp .org/content/dam/egypt/docs/Publications/Docs\%20Governance/Pathways_1110 _Cairo\%2oReport\%2oWEB_FINAL.pdf (accessed on 5 April 2016).

Uppsala Conflict Data Program (UCDP) (2016) UCDP Conflict Encyclopedia (Uppsala University Department of Peace and Conflict Research) http://www.ucdp.uu.se (accessed on 6 April 2016).

Waterbury, J. (1994) 'Democracy Without Democrats? The potential for political liberalization in the Middle East', in G. Salameh (ed.) Democracy Without Democrats? The Renewal of Politics in Muslim World (London: I.B. Tauris). 